\title{
PORK PRODUCTION AND CONSUMPTION ISSUES FROM THE PERSPECTIVE OF THE RELIGION AND THE WORLD'S GROWING POPULATION
}

\author{
${ }^{1}$ Viktoria Vida, ${ }^{2}$ István Szúcs \\ ${ }^{1}$ University of Debrecen, Faculty of Economics and Business, Institute of Applied Economics Sciences, \\ Böszörményi street 138., Debrecen, Hungary 4032 \\ ${ }^{2}$ University of Debrecen, Faculty of Economics and Business, Institute of Applied Economics Sciences, \\ Böszörményi street 138., Debrecen, Hungary 4032 \\ ${ }^{1}$ vida.viktoria@econ.unideb.hu \\ ${ }^{2}$ szucs.istvan@econ.unideb.hu
}

\begin{abstract}
In this article we would like to present the production and consumption issues of pork meat in the world. We intend to examine the production and consumption of pork meat from the point of view of the population. The growing population of the world requires an increasing amount of food, especially animal source of protein, ie meat. We want to examine how the world can supply the growing population with food, including (pork) meat. The growing population generates ever-increasing consumption from year to year, and may not be able to satisfy it, adequately supplying the population with food, especially (pork) meat. Livestock farming, especially extensive animal husbandry, will be less able to produce sufficient quantities of meat for the growing needs.

During the analysis of food (meat) data we would like to present the difference between each continent on both the production and the consumption side. Examining the pork consumption, it should be mentioned the differences in the cultural habits, because the pork meat is the most affected in religious restrictions, regulations. The religious affiliation/identity is basically determined by the food and consumer habits, too. Due to the differences in dietary habits and religious culture, we think that the consumption of pork can be highly variable in the world and from country to country as well.

In general, we would like to answer questions about how the world (pork) meat production is going, is the meat consumed in the countries where it is produced (export - import issues), what are the factors that influence (pork) meat consumption (culture and religion impact on pork consumption, animal health issues), and is there enough (pork) meat for the world's growing population.
\end{abstract}

Keywords: pork meat consumption, population growth, $A S F$

(JEL Classification: P46, Q18, Q56 )

\section{INTRODUCTION}

It is generally agreed that population growth, together with an increase in average per capita incomes, will result in higher pressure on natural resources and biodiversity (e.g. Foley et al., 2011). Feeding, housing and meeting the other needs of more than 9 billion people in the coming two to three decades will pressures on ecosystems worldwide. People living in cities now outnumber those living in rural areas (United Nations, 2014). Projections indicate that population growth in cities and small rural towns, along with the number of people migrating from rural to urban areas, will continue to increase (FAO, 2019B).
One of the most important challenges of the world to produce enough food for the growing population of the Earth. The food production needs to be increased not only because of the growth in population but also because of the changing dietary habits. While the agriculture tries to produce more food they have to solve several problems. Increasing need for water, soil degradation and climate change - these are only a few of the most important problems we are facing right now (Kőmíves et al., 2019).

The world's population continues to grow and over the next 40 years, agricultural production will have to increase by some $60 \%$. Higher food, feed and fiber demand will place 
an increasing pressure on land and water resources, whose availability and productivity in agriculture may themselves be under threat from climate change. The additional impact on food prices of higher demand for crops as energy feedstock is of real concern (Popovics et al., 2006, Popp et al., 2013).

However, the percentage of the world population living in urban areas grew from $33 \%$ to $54 \%$ over the same period, or from 1.01 billion to 4.2 billion in absolute terms (United Nations, 2014). It has been predicted that this number will rise to $68 \%$ by 2050 (United Nations, 2018). The global rural population is now close to 3.4 billion and is expected to rise slightly and then decline to around 3.1 billion in 2050. Urban population growth will, therefore, not mean an "emptying" of the countryside in the near future, at least at global level. At regional or local levels, however, there are already cases of rural depopulation, fuelled largely by outmigration to neighbouring, or more distant, town or cities, or to other countries (Gray and Bilsborrow, 2014; Chen et al., 2014).

Globally, urban development is a significant direct driver of land-use change, deforestation and habitat fragmentation (Elmqvist et al., eds., 2013). However, it also has numerous effects on (inter alia) lifestyles and consumption patterns, social and political attitudes, and the organization of production and supply chains, all of which can have knock-on effects on biodiversity, on a range of scales. For example, as people move to cities they tend to depend increasingly on purchased foods, often from a few supermarket chains (Macfadyen et al., 2015). They often also tend to lose ties with rural areas and rural foods, and increasingly opt for processed foods rather than fresh foods (Popkin, 2017).

The international food trade has undergone major changes both horizontally and vertically in recent decades. Concentration is growing worldwide for hypermarkets and supermarkets, discount stores, and for wholesalers also (Fenyves et al., 2017).

While supermarkets and other modern retailers can make a more diverse diet available and accessible to more people, they can also encourage the consumption of energy-dense, nutrient-poor, highly processed foods and reduce the ability of marginalized populations to purchase the food needed for a high-quality diet (Hawkes, 2008). This often has negative consequences for nutrition. Urban consumption patterns are also associated with a greater proportion of food going to waste (Parfitt, Barthel and Macnaughton, 2010).

The world's population doubled during the last 50 years, while the meat production of the world increased more than fourfold (Szőllősi et al, 2017). Poultry meat production increased the most significantly, because intensively kept broiler is seen as a way of rapidly increasing animal protein supplies for rapidly increasing urban populations (Szőllősi et al, 2014).

According to the predictions of OECD-FAO (2018), further increase of the population is expected, potentially reaching 10 billion people by 2060. It is the task of the near future to provide the world's population with proper quality food with high nutrient content that is important for maintaining a healthy life. On a worldwide scale, foods of animal origin represent an increasingly high proportion; therefore, animal husbandry and the connected processing industry have a significant role in feeding the world (Horn - Sütő 2014). Based on the related predictions, the meat production of the world is expected to increase by 32 million tons in the upcoming decade, but the change of the proportions of each meat type is going to show a different scale. According to FAO statistics, poultry meat production nearly doubled in the last two decades, while the amount of pork production increased to a lesser extent. As a result, the amount of poultry meat produced in the world in 2016 (116.8 million tons) exceeded the amount of pork produced in the same year (116.4 million tons), but the proportion of poultry and pork was different in the various examined countries and regions. In 2016, the EU 28 produced $65 \%$ more pork (23.6 million tons) than poultry (14.3 million tons) and this proportion is not expected to significantly change in the upcoming decade either (FAO, 2017).

The aims of this study are understanding the demographic changes that are likely to unfold over the coming years, as well as the challenges and opportunities that they present for achieving sustainable development and sustainable pork (meat) consumption. It is important to examine and calculate the "real" per capita consumption among those people who consume pig meat, because this new calculated data gives a closer look at the real numbers and the real consumers.

\section{MATERIALS AND METHODS}

To evaluate the growth of the world population, the urbanization we examined several forecasts: FAO, OECD, United Nations and other statistical reports and databases, we used tables, figures, diagrams to illustrate these projections.

The food sector is an important sector within the economy and no similar study has been made in the past (Fenyves et al., 2018). In this study, we did a calculation analysis to adjust the per capita consumption of pork in the world. The available data is relatively difficult to obtain and several sources had to be examined to find the appropriate, relevant data for the calculation. The required data on pork consumption were obtained on the FAOSTAT database, where the latest data are from 2018. World population data and religious affiliation were calculated based on Pew Research Center website. The calculation methodology is structured by first identifying the total amount of consumption in the world from the FAOSTAT database in kilograms, and then the world population in head. These two data gives the ratio of per capita pork consumption in the world, in kilograms for that year. After that we divided the world's population - according to Pew Research Center data - by using ratios of different religions. By dividing the world's population by religion, we add up those people who do not consume pork because of their religious affiliation, cultural differences, restrictions (Muslim, Hindu, Buddhist, Jewish people). Then we deducted this result from the world's global population. So we identified the world population that is not religiously restricted in pork consumption, they are the "real pork consumers". After that we divided the total pork consumption in the world (kilograms) with the "real pork 
consumers" (per capita), resulting the world corrected pork consumption indicator (kilograms / capita / year).

\section{RESULTS AND DISCUSSION}

Nowadays, the world population continues to grow more slowly than in the recent past. Ten years ago, the world population was growing by $1.24 \%$ per year, in 2014 it is growing by $1.18 \%$ per year, and it gives approximately an additional 83 million people annually. The world population is projected to increase by more than one billion people in 2030, reaching 8.5 billion people, and to increase further to 9.7 billion in 2050 and 11.2 billion by 2100 (UN, 2015).

The global trends shows considerable differences across and within regions and between high-income and middle- and low-income countries. Figure 1 show, while the high-income countries would reach their maximum population size by 2040 , low- and middle-income countries would see only slow declines in growth over the medium and even the longer term. There are also considerable differences in population growth rates within low-income countries. Asia, the most populous continent, would reach its population peak between 2050 and 2060. East Asia is expected to see a continued and increasing deceleration of growth rates and a shrinking overall population after 2040. South Asia will continue to grow beyond 2070 and only reach its zenith sometime after that point. Growth is also expected to slow in Latin America, but more moderately, and the region will not reach its maximum population size before 2060 (FAO, 2017).

In sharp contrast, the population of Europe are expected to decrease between 2015 and 2050. Several countries are expected to see their populations decline by more than $15 \%$ by 2050, including Bosnia and Herzegovina, Bulgaria, Croatia, Hungary, Japan, Latvia, Lithuania, Republic of Moldova, Romania, Serbia, and Ukraine. Fertility in all European countries is now below the level required for full replacement of the population in the long run (around 2.1 children per woman, on average), and in the majority of cases, fertility has been below the replacement level for several decades (UN, 2015). Since 2000, the population of EU 28 has grown by around $0.5 \%$ per year (Gløersen et al., 2016).

Figure 1: World population growth by continent from 1950 to 2100

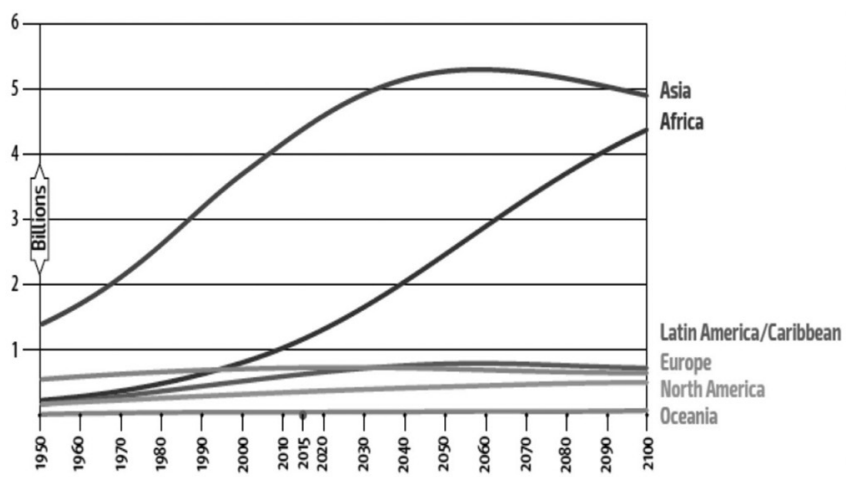

Source: FAO, 2017
Rapid growth is projected for the Near East and North Africa region, where increases come to a halt only after 2080. The only region where the maximum population size will not be reached within this century is Africa. While the region's growth rate will continue to decelerate, its population is set to continue to expand beyond the end of the century and is expected to reach more than 2.2 billion by 2050 and more than 4 billion by 2100 . The net effect across all regions will be a continuously growing global population, possibly surpassing 11.2 billion people by 2100 (FAO, 2017).

More than half of global population growth between now and 2050 is expected to occur in Africa. Africa has the highest rate of population growth among major areas, growing at a pace of $2.55 \%$ per year. The differences within regions are even more pronounced than the differences across regions. Some countries are currently projected to grow so rapidly that their populations would reach multiples of their current levels by 2050 . At the top of the list of fast growing populations is Niger, with growth rates of $3.75 \%$ expected between 2015 and 2050 , and $2.12 \%$ thereafter (UN, 2015).

The new projections include some notable findings at the country level. For example, within seven years, the population of India is expected to surpass that of China. Currently, the population of China is approximately 1.38 billion compared with 1.31 billion in India. By 2022, both countries are expected to have approximately 1.4 billion people. Thereafter, India's population is projected to continue growing for several decades to 1.5 billion in 2030 and 1.7 billion in 2050, while the population of China is expected to remain fairly constant until the 2030s, after which it is expected to slightly decrease.

For decades, the world's population was predominantly rural. We can see on the Figure 2 that, thirty-five years ago, more than 60 percent of all people lived in rural areas. Since then, the urban-rural balance has changed markedly, and today slightly more than half of the global population (54\%) is urban. Thirty-five years from now, in 2050, more than twothirds of all people may be living in urban areas (FAO, 2017).

Figure 2:

Growth in global urban and rural populations from 1950 to 2050

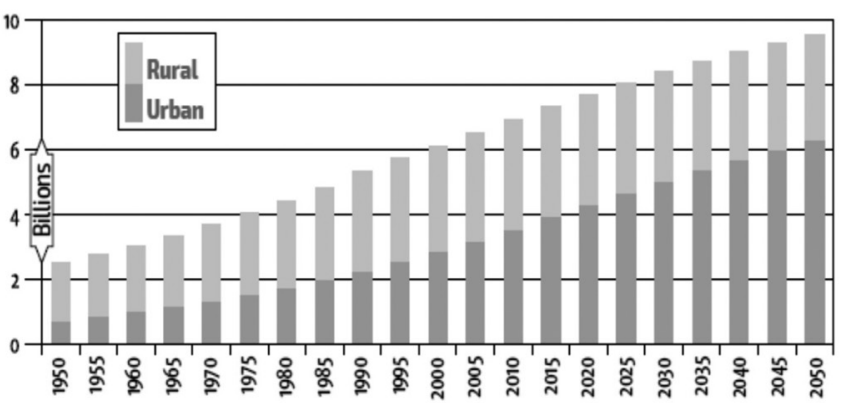

Source: FAO, 2017

Changes in agriculture, notably technical progress and the adoption of labour-saving technologies, have helped underpin increasing urbanization. At the same time, agriculture, 
food and nutrition have been, and are likely to continue be, affected by the changes brought about by urbanization (FAO, 2017). Consumption of cereals and other crops will decline while consumption of vegetables, fruits, meat, dairy products and fish is expected to increase. Increasing demand for semi-processed or ready-to-eat foods will lead to further concentration in the food chain (FAO, 2011).

To sum up the most important effects of urbanization on the food industry are: changing consumer habits, increasing demand for processed foods; the increasing importance of retail chains in distribution; increasing food wastage, which is more concentrated; increasing the distance between the place where food is produced and consume; increasing packaging; people are moving away from nature; people do not want / can prepare food ingredients (e.g. peeled vegetables, etc.), they also want to buy it.

In addition to urbanization, the culture, the religion affects our food consumption too. Religious groups have independent beliefs, attitudes and rules. There are some religious restrictions that have a significant impact on food consumption. The three most significant are the Muslim, Hindu and Israeli populations. We can see on the Table 1 that, the highest proportion / number of people has the Christians, this religion hasn't got any restriction in food consumption. The second biggest number has the Muslims, and the third the Hindus. There are restrictions in Hindu, Muslim and Jewish religion. The Hindus does not consume beef meat, and there are many vegetarians among the Hindus. In Jewish and Muslim religion do not consume pork meat. The Jewish population won't be growing significantly, but the number of Muslims will increase in the future. From 2010 to 2050 the proportion of Muslims from 23\% will grow to around $30 \%$, and to 2100 it will be more than $31 \%$, it will be as the same, like Christians.

Table 1: The number of the main religious groups

\begin{tabular}{|l|l|l|l|l|}
\hline $\begin{array}{l}\text { The main } \\
\text { religious } \\
\text { groups }\end{array}$ & $\begin{array}{l}\text { Population } \\
\text { in 2010 } \\
\text { (thousand } \\
\text { people) }\end{array}$ & $\begin{array}{l}\text { \% of world } \\
\text { population in } \\
2010\end{array}$ & $\begin{array}{l}\text { Projected } \\
\text { population } \\
\text { in 2050 } \\
\text { (thousand } \\
\text { people) }\end{array}$ & $\begin{array}{l}\text { \% of world } \\
\text { population in } \\
2050\end{array}$ \\
\hline Christians & $2,168,330$ & 31.4 & $2,918,070$ & 31.4 \\
\hline Muslims & $1,599,700$ & 23.2 & $2,761,480$ & 29.7 \\
\hline Unaffiliated & $1,131,150$ & 16.4 & $1,230,340$ & 13.2 \\
\hline Hindus & $1,032,210$ & 15.0 & $1,384,360$ & 14.9 \\
\hline Buddhists & 487,760 & 7.1 & 486,270 & 5.2 \\
\hline $\begin{array}{l}\text { Folk reli- } \\
\text { gions }\end{array}$ & 404,690 & 5.9 & 449,140 & 4.8 \\
\hline $\begin{array}{l}\text { Other reli- } \\
\text { gions }\end{array}$ & 58,150 & 0.8 & 61,450 & 0.7 \\
\hline Jews & 13,860 & 0.2 & 16,090 & 0.2 \\
\hline World total & $6,895,850$ & 100.0 & $9,307,190$ & 100.0 \\
\hline
\end{tabular}

Source: own construction based on projection of the Pew Research Center, 2015
We can conclude from Table 1 that, the proportion of Christians (31\%) and Hindus (15\%) will be the same in 2050, the number of Muslims will be increase (from 23\% to 30\%), and the proportion of another religion groups will decrease in the future.

To sum up, we can state, that the growing population in Asia and Africa with the religious Muslim, or Hindus will not be increase the pork consumption and pork production. Whereas these religious groups do not consume pork due to the restriction, pork is not affected by their growing population.

We can see in Table 2 the meat production and trade by the types of meat in 2017 and 2018.

Table 2: The world meat market (production, trade, consumption) in 2017 and 2018

\begin{tabular}{|l|l|l|l|}
\hline $\begin{array}{l}\text { PRODUCTION (million } \\
\text { tons) }\end{array}$ & 2017 & 2018 & 2019 forecast \\
\hline Bovine meat & 69,6 & 71,2 & 71,6 \\
\hline Poultry meat & 122,3 & 124,8 & 128,4 \\
\hline Pork meat & 119,8 & 120,5 & 115,6 \\
\hline Ovine meat & 15,2 & 15,2 & 15,3 \\
\hline Total meat production & 332,4 & 337,3 & 336,5 \\
\hline TRADE(million tons) & 10,2 & 10,9 & 11,3 \\
\hline Bovine meat & 13,1 & 13,3 & 13,8 \\
\hline Poultry meat & 8,2 & 8,4 & 9,1 \\
\hline Pork meat & 1,0 & 1,0 & 1,0 \\
\hline Ovine meat & 32,8 & 33,8 & 35,4 \\
\hline Total meat trade & 43,9 & 44,0 & 43,4 \\
\hline Per capita meat consump- & & & \\
\hline
\end{tabular}

Source: own construction based on FAO, 2019A

World meat output in 2019 is forecast to drop by $0.2 \%$ to nearly 337 million tonnes, breaking the pattern of slow but steady growth witnessed by the sector for almost two decades. The decline in global meat production fundamentally reflects the expectations of a $5 \%$ output contraction in China, along with a slight decline in anticipation of all major meat producing countries, especially the United States of America, Brazil, Mexico, India, the European Union (EU), the Russian Federation and Pakistan. World trade in meat and meat products is forecast to surpass 35 million tonnes in 2019, up $4.8 \%$ from last year. Much of the momentum is expected to stem from a 19-20\% surge in overall meat imports by China, partly because of the ASF spread. Elsewhere, Japan, Mexico, the Philippines, Viet Nam and the Russian Federation are also expected to step up their meat purchases, while Saudi Arabia, Angola, Cuba and the Republic of Korea may import less. The expected expansion in world import demand is forecast 
to be largely met by increased exports from Brazil, the EU, the United States of America, Thailand, India and Argentina, while limited supplies may depress meat sales by Australia, New Zealand, China and Uruguay (FAO, 2019A).

Another remarkable information that today, an average person eats 44 kilograms of meat per year, and it will reach 52 kilograms of meat per year to 2050 (FAO, 2017). When we compare consumption across different countries we see that, typically, the richer we are the more meat we eat. There are not just more people in the world, there are more people who can afford to eat meat.

We can see in the Table 3 the production, trade and consumption data of pork meat (in carcass weight equivalent). The production is projected to increase in the future (it will reach 128 million tons to 2025) but has not yet been calculated with ASF. The import and export are on the same level, around 8 million tonnes, the export has always a little higher data. The export-import level will grow to 2027 to 8.5 million tonnes. It is a very slight growth for the future.

Table 3: The world pork meat market (production, trade, consumption) in thousand tons 2017-2025

\begin{tabular}{|l|c|c|c|c|c|c|c|c|c|}
\hline $\begin{array}{l}\text { Pork meat } \\
\text { (cwe) }\end{array}$ & 2017 & 2018 & 2019 & 2020 & 2021 & 2022 & 2023 & 2024 & 2025 \\
\hline Production & 118 & 120 & 121 & 123 & 124 & 125 & 126 & 127 & 128 \\
554 & 708 & 854 & 150 & 400 & 644 & 730 & 758 & 807 \\
\hline Imports & 8120 & 7963 & 7921 & 7972 & 8035 & 8085 & 8116 & 8183 & 8282 \\
\hline Exports & 8295 & 8140 & 8098 & 8149 & 8212 & 8262 & 8293 & 8359 & 8459 \\
\hline $\begin{array}{l}\text { Consump- } \\
\text { tion }\end{array}$ & 118 & 120 & 121 & 122 & 124 & 125 & 126 & 127 & 128 \\
\hline
\end{tabular}

Source: own construction based on OECD-FAO, 2018

According to recent FAO reports global pig meat production is forecast at 115.6 million tonnes, a decline of $4.0 \%$ from 2018. The contraction principally reflects a sharp fall in China, which is expected to outweigh expansions especially in the United States of America, Brazil and the Russian Federation. Meanwhile, pig meat output in the EU is forecast to remain stable (FAO, 2019A). The biggest pork importer countries are China, Japan, Mexico, Republic of Korea, and USA. These five country takes $70 \%$ of the global import, China has only alone a huge effect of global import. China could alone realign the map of the world pork meat market. The main exporter countries are EU 28, USA, Canada, Brazil, and Mexico. These five country takes $92 \%$ of the global export, it is a very large figures. It is thoughtful that these 5 countries transact almost the whole trade of pork.

If we focusing only for pork consumption, we can conclude that is $12,3 \mathrm{~kg}$ per year for an average people in the world (OECD-FAO, 2019). But previously we talked about religion rules that has significantly effect for pork consumption, because Jewish, Muslims and maybe Hindus doesn't consume pork. So we corrected this per capita pork consumption FAO data, so we divided the population into religious groups, and we removed the number of Muslim and Jewish population, and divided this data (population) with the utilization of pork meat, and we get the $20.6 \mathrm{~kg} /$ year consumption level of pork. In the second case we corrected the number of population even with the Hindus. This two corrected data is very far from the FAO data, nearly double. This way we can get the real pork consumers, who eat a lot more pork, than we think, and the FAO statistic said. Consumption data of poultry is only 14.2 $\mathrm{kg}$, so we can conclude (in this case) that pork is the most consumed meat.

In addition to the factors mentioned above, there are some sudden changes, which may transforming the pork meat consumption in the world. The outbreak of African Swine Fever (ASF) in East Asia (especially China) is having a strong impact on meat markets.

Reports by government officials, industry sources and news media suggest that around $20 \%$ of China's pig inventories had already been culled in the first few months of 2019, amid fears of ASF spreading more rapidly. In many provinces, cull rates in excess of 20\% have been reported (FAO, 2019A).

To take a closer look of ASF in China, the Ministry of Agriculture announced that July's pig and sow inventory had decreased $32.2 \%$ and $31.9 \%$ from July a year ago. If we use China's inventory of 440.6 million in 2018 (Table 4) that decreased with $32.2 \%$, we can calculate a decrease of 140 million pigs compared to a year ago. That decline is almost equal to all the pigs in Europe. We suspect that China's government estimate of $32.2 \%$ decline could be conservative. All observers' projects 50\% range. There is a massive decline of pork supply in China, and it will be a huge increase in China's import. It would be huge pressure on the Chinese government to increase pork and other meat imports to hold food prices down. African Swine Fever could be a problem in other countries, because it will be observed in Mongolia, and several countries in Europe (Internet 1.).

Table 4: Numbers of pigs in the world in 2018

\begin{tabular}{|l|l|l|}
\hline & Million pigs in 2018 & $\%$ \\
\hline China & 440,60 & $56 \%$ \\
\hline European Union & 150,26 & $19 \%$ \\
\hline United States & 73,15 & $9 \%$ \\
\hline Brazil & 38,83 & $5 \%$ \\
\hline Russia & 22,94 & $3 \%$ \\
\hline Canada & 14,17 & $2 \%$ \\
\hline South Korea & 11,27 & $1 \%$ \\
\hline Mexico & 10,41 & $1 \%$ \\
\hline Japan & 9,28 & $1 \%$ \\
\hline Other & 10,00 & $3 \%$ \\
\hline Total & 780,91 & $100 \%$ \\
\hline
\end{tabular}

Source: Internet 1. 
In China, official notifications had confirmed 129 ASF outbreaks and the culling of more than 1 million pigs by April 2019. In addition to culling, in an effort to keep the spread in check, the Government is creating separate, selfsufficient zones and ban the cross-regional transport of animals and products. However, the continued relevance of backyard farming and the use of food waste as animal feed make controlling the spread extremely challenging. There is a lively exchange of all sorts of pork products within the region, including sausages, cured meats and other processed pig meat products. They may all contain the ASF virus, which is highly resistant to temperature and other treatments (salting) and can persist for months or years. This means that the chances of ASF to spread far and fast are not only high, but the disease may resurface in the region even years after the initial outbreak (FAO, 2019A).

Due the ASF the newest data shows significant rise in global demand, production of EU pork meat for exports is expected to increase in the short term. The EU and the Americas are expected to increase their exports to satisfy world pork meat demand. High prices could lead to a stronger decline in EU consumption than previously anticipated. In the case of the Americas, per capita consumption will also rise (EC, 2019).

\section{SUMMARY}

According to the latest reports we can conclude, that the world's population by 2050 will reach 9.1 billion. This population growth will increase primarily in developing countries. Urbanization will continue rapidly, and it will also affect food consumption patterns. Income levels will be many times higher than they are today, more and more people can afford to buy (pork) meat. The pork meat consumption will be change significantly in the future, the reasons are in addition to population growth and urbanization will be religion issues, environmental/climate problem, healthy lifestyle, lower meat availability on the market. Feed this larger, more urban and richer population will be a big challenge of the 21st century.

These affecting factors will lead to change the consumer basket, the reason for the change in the consumption structure will vary from country to country. These consumer changes will have a major impact on food production and trade also. Changing consumption patterns especially in pork meat will lead to changes in the structure of meat production, it could lead to further consumption shifts between meat types. Poultry meat is expected to continue gaining shares in total meat consumption.

Religious rules have a significant impact on pork consumption and thus on the geographical distribution of pork meat. The reason for this is to be found in religious restrictions, because Jewish, Muslims doesn't consume pork under no circumstances. This is why we corrected in this study the per capita pork consumption FAO data, to show a real picture of pork consumption. After the calculation we get two corrected data, they are very far from the FAO per capita pork meat consumption data $(12.3 \mathrm{~kg} / \mathrm{capita} /$ year$)$, nearly double. After this consumption calculation we examined the pork meat production, trade, and within the role of China. We can conclude that, China is the biggest pork producer, consumer and importer country. The effect of pork meat issues is huge, China could alone realign the world meat map.

The appearance of African Swine Fever (ASF) in China, with its impacts on production, consumption and trade, represents the most significant factor currently shaping the world meat market (FAO, 2019A). From this point of view, population growth is not the biggest challenge at the moment, but also to stop the spread of ASF. In the near future we have to count the consumption of beef and poultry will increase in China; and the prices may move upwards in all types of meat. Due to the recent outbreak of African swine fever (ASF) in Asia, there is a lot of uncertainty about the future world meat demand.

To sum up, demand is undergoing structural changes due to factors such as population growth, urbanization, religion issues, increasing per capita income, and other trends in meat consumption are to be considered, for example changing dietary patterns (vegetarians, vegans), the knowledge of the origin of meat (e.g. animal welfare) and how it has been produced (e.g. organic, environmental footprint).

\section{ACKNOWLEDGMENTS:}

This work was supported by EFOP3.6.3-VEKOP-16-201700007-“Young researchers for talent" - Supporting careers in research activities in higher education program.

\section{REFERENCES}

Chen, R., Ye, C., Cai, Y., Xing, X. \& Chen, Q. (2014): The impact of rural out-migration on land use transition in China: past, present and trend. Land Use Policy, 40: pp. 101-110.

EC (2019): EU agricultural outlook for markets and income, 2019-2030. European Commission, DG Agriculture and Rural Development, Brussels. ISBN: 978-92-76-15381-8. 94 p. Available at: https:/ec.europa.eu/info/sites/info/files/food-farmingfisheries/farming/documents/agricultural-outlook-2019-report en.pdf

Elmqvist, T., Fragkias, M., Goodness, J., Güneralp, B., Marcotullio, P.J., McDonald, R.I., Parnell, S. et al. (2013): Urbanization, biodiversity and ecosystem services: challenges and opportunities. A global assessment. Dordrecht, Netherlands, Springer, 2013. 775p. DOI: 10.1007/978-94-007-7088-1.

Gløersen E., Drăgulin M., Hans S., Kaucic J., Schuh B., Keringer F., Celotti P. (2016): The impact of demographic change on European regions. ISBN 978-92-895-0867-4. Published: European Union, 2016. 147 p. DOI: 10.2863/26932.

FAO (Food and Agriculture Organization of the United Nations) (2011): World Livestock 2011 - Livestock in food security. ISBN 978-92-5-107013-0. Published: FAO. Rome, 2017. 130 p. 
FAO (Food and Agriculture Organization of the United Nations) (2017): The Future of Food and Agriculture - Trends and Challenges. ISBN 978-92-5-109551-5. Published: FAO. Rome, 2017. $180 \mathrm{p}$.

FAO (Food and Agriculture Organization of the United Nations) (2018): World Food And Agriculture - Statistical Pocketbook 2018. ISBN 978-92-5-131012-0. Published: FAO. Rome, 2018. 254 p.

FAO (Food and Agriculture Organization of the United Nations) (2019A): Food Outlook - Biannual Report on Global Food Markets. ISBN: 978-92-5-131448-7. Published: FAO. Rome, 2019. 158 p.

FAO (Food and Agriculture Organization of the United Nations) (2019B): The State of the World's Biodiversity for Food and Agriculture, J. Bélanger \& D. Pilling (eds.). FAO Commission on Genetic Resources for Food and Agriculture Assessments. ISBN 978-92-5-131270-4. Rome. 572 p.

Fenyves V., Tarnóczi T., Nagy A. (2017): Pénzügyi kimutatások elemzése klaszterelemzés segítségével az Észak-alföld Régióban múködô élelmiszer-kiskereskedelmi vállalkozásoknál. ACTA CAROLUS ROBERTUS Volume 7. Issue 1. pp. 87-103. Paper: 17. DOI: 10.22004/ag.econ.261846

Fenyves V., Bács Z., Karnai L., Nagy A., Tarnóczi T. (2018): Financial Performance Measurement of Hungarian Retail Food Companies. CONTEMPORARY ECONOMICS Volume 12. Issue 4 pp. 459-471., 13 p. DOI: 10.5709/ce.1897-9254.290

Foley, J.A., Ramankutty, N., Brauman, K.A., Cassidy, E.S., Gerber, J.S., Johnston, M., Mueller, N.D. et al. (2011): Solutions for a cultivated planet. Nature, 478 (7369): pp. 337-342. DOI: $10.1038 /$ nature10452.

Gray C. L., Bilsborrow R. E. (2014): Consequences of outmigration for land use in rural Ecuador. Land Use Policy, Volume 36, January 2014, pp. 182-191. DOI: 10.1016/j.landusepol.2013.07.006.

Hawkes, C. (2008): Dietary implications of supermarket development: a global perspective. Development Policy Review, Volume 26 (6): pp. 657-692. DOI: 10.1111/j.1467-7679.2008.00428.

Horn P., Sütő Z. (2014): A világ baromfihús-termelése és az előállítás versenyképessége. Acta Agraria Kaposváriensis 18(1), pp. 14-29.INTERNET 1. https://www.swineweb.com/jim-longpork-commentary-china-pig-herd-continues-massive-declineaugust-19th-2019/

Kőmíves P. M., Pilishegyi P., Novák N., Nagy A. Sz., Körösparti P. (2019): The Role of the Higher Education in the Development of the Agriculture. INTERNATIONAL JOURNAL OF INFORMATION AND EDUCATION TECHNOLOGY 9: 9 pp. 607-612., 6 p.
Macfadyen, S., Tylianakis, J.M., Letourneau, D.K., Benton, T.G., Tittonell, P., Perring, M.P., Gómez-Creutzberg, C. et al. 2015. The role of food retailers in improving resilience in global food supply. Global Food Security, Volume 7, December 2015: pp. 1-8 DOI: 10.1016/j.gfs.2016.01.001

OECD-FAO (2018): OECD-FAO Agricultural Outlook 2018-2027. Available at: https://stats.oecd.org/Index. aspx?datasetcode $=$ HIGH_AGLINK_2017

OECD-FAO (2019): OECD-FAO Agricultural Outlook 20192028. OECD Publishing, Paris. ISBN: 978-92-6-431246-3. Available at: https://data.oecd.org/agroutput/meat-consumption.htm DOI: 10.1787/agr_outlook-2019-en

Parfitt, J., Barthel, M., Macnaughton, S. (2010): Food waste within food supply chains: Quantification and potential for change to 2050. ISSN: 0962-8436. Published: Royal Society, Volume 365 (1554): pp. 3065-3081. DOI: 10.1098/rstb.2010.012

Pew Research Center (2015): Demographic Study: The Future of World Religions: Population Growth Projections, 2010-2050. April 2, 2015. 245 p. Available at: https://assets.pewresearch. org/wp-content/uploads/sites/11/2015/03/PF_15.04.02_ProjectionsFullReport.pdf

Popkin, B. (2017): Relationship between shifts in food system dynamics and acceleration of the global nutrition transition. Nutrition Reviews, Volume 75 (2): pp. 73-82. DOI: 10.1093/ nutrit/nuw064.

Popovics P. A., Tóth J. (2006): Az ártranszmisszió és az árak aszimmetrikus hatásának vizsgálata Magyarország tejvertikumában. Közgazdasági Szemle ISSN 0023-4326. LIII. évfolyam, 4. szám. Budapest, 2006. április. pp. 349-365.

Popp J., Harangi-Rákos M., Pető K., Nagy A. (2013): Bioenergy: Risks to food-, energy- and environmental security. In: APSTRACT - Applied Studies in Agribusiness and Commerce. ISSN 1789-7874. Center-Print Publishing House, Debrecen. Volume 7. Number 4-5 pp. 121-130., 10 p. DOI: 10.19041/APSTRACT/2013/4-5/17

Szőllősi L., Szű́cs I., Nábrádi A. (2014): Economic issues of broiler production length. In: Economics of Agriculture. ISSN 2334-8453. Volume 61. Number 3. pp. 633-646. Available at: http://www.ea.bg.ac.rs/index.php/EA/article/view/353 DOI: 10.5937/ekoPolj1403633S.

Szőllősi L., Molnár Sz., Ladányi K., Karnai L., Szűcs I. (2017): Cost analysis of pig slaughtering: A Hungarian case study. In: APSTRACT - Applied Studies in Agribusiness and Commerce. ISSN 1789-7874. Center-Print Publishing House, Debrecen. Volume 11. Number 3-4. 121-130 p. DOI: 10.19041/ APSTRACT/2017/3-4/17. 
United Nations, Department of Economic and Social Affairs, Population Division (2014): World Urbanization Prospects: The 2014 Revision, Methodology Working Paper No. ESA/P/ WP.238. Available at: https://population.un.org/wup/Publications/Files/WUP2014-Methodology.pdf

United Nations, Department of Economic and Social Affairs, Population Division (2015): World Population Prospects: The 2015 Revision, Key Findings and Advance Tables. Working Paper No. Available at: ESA/P/WP.241. https://population.un.org/ wpp/publications/files/key_findings_wpp_2015.pdf

United Nations, Department of Economic and Social Affairs, Population Division (2019): World Urbanization Prospects: The 2018 Revision (ST/ESA/SER.A/420). ISBN: 978-92-1-1483192. Published by the United Nations. Available at: https://population.un.org/wup/Publications/Files/WUP2018-Report.pdf 